\title{
Research on the Point-Based Evaluation System of Young Teachers at Private Colleges and Universities
}

\author{
Weihuang Dai*, Lin Yang, Jiao Zeng, Fei Deng \\ South China Business College, Guangdong University of Foreign Studies, Guangzhou, China \\ Email: $975690566 @ q q . c o m$
}

How to cite this paper: Dai, W.H., Yang, L. and Zeng, J. and Deng, F. (2018) Research on the Point-Based Evaluation System of Young Teachers at Private Colleges and Universities. Open Journal of Social Sciences, 6, 106-114.

https://doi.org/10.4236/jss.2018.68008

Received: March 4, 2018

Accepted: August 18, 2018

Published: August 21, 2018

Copyright ( 2018 by authors and Scientific Research Publishing Inc. This work is licensed under the Creative Commons Attribution International License (CC BY 4.0)

http://creativecommons.org/licenses/by/4.0/

\begin{abstract}
At present, young and mid-aged teachers account for a substantial proportion in the teaming staffs at private colleges and universities. Young teachers are the core of the development of private colleges and universities, so it is extremely urgent to apply the modern human resource management concept to reform the private colleges and universities. This paper analyzes the problems existing in the construction of the current private colleges and universities, and proposes a point-based evaluation system for young teachers. By combining the evaluation system and the compensation system, we will stimulate the behavior of teachers with competitive advantages, promote the development of young teachers, and maximize the value and value-added of teachers.
\end{abstract}

\section{Keywords}

Private Colleges and Universities, Young Teachers, Point-Based, Evaluation System

\section{Introduction}

After more than 30 years of development, private colleges and universities have become an important part of higher education in China. From the perspectives of the number of schools, the scale of running schools, and the characteristics of running schools, private colleges and universities have made great progress and achievements, and the pattern of complementary and coordinated development with public universities has basically taken shape. From the beginning of school to the growth and development, on the core problem for all universities rely is quality. Quality is the lifeline of higher education. The key to improving the quality of running a school is the teacher. The construction of the teaching team 
is the key. The overall level of the teaching team marks the level of running a university and is also a key factor in determining the quality of student training. French educator Durkheim E. said: "The success of education depends on the teacher, and the unsuccessful education depends on the teacher." Without teachers, a school cannot be formed; without a high-quality teaching team, there is no high-quality school quality. Therefore, teachers bear the important responsibility and important mission of running a satisfactory education for the country and the people.

However, due to the late start of our private colleges and universities, the faculty presented a "dumbbell" status, which is the irrational age structure of "old" and "less" teachers. Young teachers are the backbone of private colleges and universities [1]. At present, the problems existing in the teaching staff of private colleges and universities are mainly in the following aspects.

1) Unreasonable Academic Degree and Title Structure of Teachers at Private Colleges and Universities.

At the beginning of the private colleges and universities, the faculty mainly relied on the part-time teachers of public universities to develop on the basis of "nothing". Due to the environment of talent introduction and the influence and constraints of various factors, the education, professional title and age structure of the private colleges and universities are unreasonable. The main body of the full-time faculty is mainly composed of undergraduate and graduate students who have just graduated. The skills and experience of teachers need to be accumulated for a long time. The other part is the retired old teachers of public universities, who have basically passed the peak of creative work. The young and middle-aged backbone teachers are seriously deficient, and high-level talents with high academic qualifications such as doctoral students are scarce [2].

2) Scientific Research Needs to Be Further Promoted among Young Teachers.

Scientific research is one of the basic tasks of university teachers. It is difficult to do a good job in teaching without university teachers [3]. The combination of teaching and research is necessary to accelerate the professional growth of young teachers. Through scientific research and engineering practice, it is possible to improve the academic level of young teachers and the ability to develop new technologies, and to achieve "combination" and "use of freedom" in theoretical teaching, thereby improving classroom teaching. In many cases, the young teachers of private colleges and universities are engaged in scientific research activities at a spontaneous stage. At the institutional level, scientific research work requirements have not yet been formed, which has greatly restricted the improvement of young teachers' scientific research capabilities.

3) Young Teacher Evaluation System Is Relatively Lagging Behind.

The teacher management system of private colleges and universities is insufficiently motivated for the development of young teachers. In the process of designing and implementing the training and development system for young teachers, there is a lack of targeted incentives for the diverse development requirements of young teachers of different professions. In addition, the current 
customary practice of private colleges and universities is to promote young teachers to participate in training through policy and administrative means, and to stipulate what training should be attended by young teachers. Teachers have lost their subjective initiative and creativity by obeying the instructions from the top down and from the outside. They have not changed "want me to develop" to "I want to develop" and have not fully exerted the right to choose self-development. At the same time, some evaluation systems do not meet the development needs of young teachers. This not only fails to motivate them, but instead binds young teachers and runs counter to the professional development expectations of young teachers [4].

4) The Task of Cultivating Young Teachers Is Arduous.

In the private colleges and universities, especially the age structure presents a "dumbbell" status. The proportion of young teachers is very large. Objectively, it is necessary to increase investment in this area, attach importance to the professional development of young teachers, and strengthen the training of young teachers, accelerate the process of the growth and development of young teachers.

The above problems and the existence of contradictions are the necessary stages in the process of reform and development of private colleges and universities. Only by transforming concepts, becoming problem-oriented and systematically studying countermeasures can the problems be effectively resolved fundamentally. The construction and management of young teachers is a problem that private colleges and universities are moving toward higher strategic goals, and the evaluation of young teachers is an important means to promote the development of young teachers. The point-based system is to use the points (points and deductions) to comprehensively quantify the human ability and comprehensive performance, and use software records and permanent use [5]. Generally speaking, the point-based system management refers to the use of points for the management of customers [6]. The point-based system mentioned in this article refers to the management of the evaluation system for young teachers. Using the points to measure the self-worth of young teachers reflects and assesses the comprehensive performance of people, and then links various welfare and material benefits with points. Young teachers with high scores can get more benefits and even resolve future affiliation in order to achieve the purpose of motivating young teachers, and fully mobilize the enthusiasm of young teachers. The author believes that it should be effective. solutions by reforming the professional development evaluation system for young teachers, combining the incentive mechanism, re-establishing the system, improving and perfecting the evaluation system for the professional development of young teachers, and gradually forming a long-term mechanism for the development and training of young teachers [7].

\section{Basic Thought of Point-Based Evaluation System}

Overall, the reform of the system to evaluation the professional development of 
young teachers at private colleges and universities should reflect the thought of "teaching-oriented, focusing on development, strict evaluation, quality assurance, contribution-based, more rewards for more work, and better rewards for better work" to encourage young teachers to be proactive.

Private colleges and universities should undertake the main task of cultivating young teachers. It is necessary to put young teachers in the top priority and effectively launch specific and scientific strategies and methods that are in line with the development trend of education [8]. The responsibility system for training young teachers should be implemented. All functional departments should work closely together to clarify their responsibilities and build a large-scale training system for young teachers. Under the premise of fairness and justice, the distribution system should be inclined to young teachers as much as possible, support young teachers to carry out teaching research and scientific research in combination with professional development, support them to participate in social practice and social services, and effectively solve the problems encountered in their professional development.

With "teachers' quality oriented, based on teaching, focusing on scientific research, rooted in development" as the basic requirement, insist on both quality and talents, focus on the ability, performance and achievements to evaluate young teachers. Adhere to the problem orientation and solve the practical problems as the starting point; follow the combination of personal growth and education rules, comprehensive assessment and highlighting, combined development evaluation and reward and punishment evaluation, scientifically formulate young teacher evaluation system, and promote the development of young teachers to high level [9]. Thus, convert the situation in which young teachers are less motivated in teaching and carrying out scientific research with unclear professional development goals.

To build a private colleges and universities point-based evaluation system, we must define the following two concepts. Young teachers: According to the statistics of the Ministry of Education on education, young teachers refer to full-time teachers who are specialized in teaching and research in colleges and universities and are under the age of 40. Integral factor: The integral factor here is not an integral factor in the mathematical field, but is based on the need to solve practical problems in the work. Simple analysis is to set certain indicators as factors, and assign corresponding score values to the factors. The integral is the accumulation of factor scores. The purpose of setting up the integral factor is to quantify the implementation of the assessment system and make the assessment more scientific.

\section{Specific Implementation of the Point-Based Evaluation System}

\subsection{Integral Factor Setting}

Strive to form a normal management system focusing on the construction and 
planning of the team of young teachers, based on the assessment of young teachers' quality, post competence and ability, practical exercises at enterprises and improvement of abilities so as to improve young teachers' political quality and their academic spirit. In order to reflect the objectivity and operability of the evaluation system, the author sets the integral project, including teacher morality, teaching, scientific research, social service, etc., refines the object of the integral project into the integral factor, and quantifies the corresponding integral factor. Young teachers learn to make progress, earn points, and quantify the points. The points are accumulated to get the total points. The integral factor is integrated according to a school year, and the scores of the young teacher evaluation integral factors are shown in Table 1 (Data from the Department of $\mathrm{Hu}$ man Resources of South China Business College of Guangdong University of Foreign Studies).

\subsection{Point-Based Evaluation Method}

1) Evaluation Organization and Implementation.

Set up a leading group for evaluation work, comprehensively guide and implement the professional development and training evaluation of young teachers, and directly responsible for guiding, assessing and supervising the evaluation work. Each secondary teaching unit shall set up a corresponding evaluation team to be responsible for the evaluation of the actual scores of the points of the young teachers in the department.

Table 1. Young teachers' evaluation integral factor setting table.

\begin{tabular}{|c|c|c|c|c|c|}
\hline \multirow{2}{*}{ Category of Points } & \multirow{2}{*}{ Point Items } & \multirow{2}{*}{ Details of Points } & \multicolumn{3}{|c|}{ Score of Points } \\
\hline & & & 3 & 2 & 1 \\
\hline \multirow[t]{3}{*}{ Teachers' quality } & Papers of teachers' quality & Participated in the provincial teacher's essay and win award & $1^{\text {st }}$ Class & $2^{\text {nd }}$ Class & $3^{\text {rd }}$ Class \\
\hline & Teaching competition & $\begin{array}{l}\text { Participated in provincial teaching competitions and win } \\
\text { awards }\end{array}$ & $1^{\text {st }}$ Class & $2^{\text {nd }}$ Class & $3^{\text {rd }}$ Class \\
\hline & Teaching team & Participate in teaching teams at all levels and is approved & Provincial & Municipal & Collegiate \\
\hline \multirow[t]{4}{*}{ Teaching } & $\begin{array}{l}\text { Teaching and research } \\
\text { project }\end{array}$ & $\begin{array}{l}\text { Presided over the application of the teaching and research } \\
\text { project and is approved }\end{array}$ & Provincial & Municipal & Collegiate \\
\hline & Guiding students & $\begin{array}{l}\text { Instruct students to participate in provincial and above } \\
\text { competitions }\end{array}$ & $1^{\text {st }}$ Class & $2^{\text {nd }}$ Class & $3^{\text {rd }}$ Class \\
\hline & $\begin{array}{l}\text { Teaching and research } \\
\text { project }\end{array}$ & $\begin{array}{l}\text { Presided over the declaration of scientific research projects } \\
\text { and is approved }\end{array}$ & Provincial & Municipal & Collegiate \\
\hline & Teaching and research team & $\begin{array}{l}\text { Participate in scientific research teams at all levels and get } \\
\text { projects }\end{array}$ & Provincial & Municipal & Collegiate \\
\hline \multirow[t]{3}{*}{ Scientific Research } & Paper publication & Calculated according to each published paper & Grade A & Grade B & Grade C \\
\hline & Patent & Calculated per patent & Grade A & Grade B & Grade C \\
\hline & Software copyright & $\begin{array}{l}\text { Each software copyright is calculated according to the } \\
\text { patented Grade C }\end{array}$ & - & - & Grade C \\
\hline Social Services & Horizontal project & $\begin{array}{l}\text { Calculated according to the school budget, able to } \\
\text { accumulate }\end{array}$ & 300,000 & 200,000 & 100,000 \\
\hline
\end{tabular}


The professional development and training of young teachers takes activities as the carrier and promotes the overall optimization of the young teachers team [10].

a) Teacher's morality and construction activities. Carry out the theme activities of teacher morality and style construction, and mobilize young teachers to strengthen their ideals and beliefs in the form of teacher's morality report, public service, integrity record, and essays, and keep up with the times and be brave in innovation.

b) Teaching promotes professional development activities. Implementing the "Teacher and Apprentice Pairing" campaign, through targeted "taking the old and bringing new, passing on the band" work, preaching and teaching, helping new teachers to grow as soon as possible. Support young teachers to use the holidays to carry out job training or participate in collaborative project research and development work in various enterprises and institutions, enrich work experience and practical experience, and enhance teaching and research capabilities.

c) Organizing teaching competitions and conducting teaching and research activities. Organize demonstration classes, lectures, lectures, assessments and other activities, as well as evaluation activities such as syllabus, courseware, lesson plans, classroom teaching and other teaching links.

d) Relying on the scientific research department to organize scientific research and social services. Support young teachers to declare scientific research topics at the school, municipal, provincial and national levels. Through research, learn about cutting-edge information, update subject knowledge, and continuously improve the teaching and research capabilities of young teachers.

e) Establish a professional teaching team, a team of innovative and entrepreneurial instructors, and give full play to the team's advantages.

f) External training and continuing education. Organize young teachers to participate in training and continuing education sponsored by the education authorities and associations to understand the academic frontiers of the discipline. Strengthen the study of educational theory and education policy, strengthen the study of professional basic theory, carry out project cooperation research, broaden the knowledge and improve the academic level.

2) Evaluation Procedures.

The evaluation of young teachers is organized and evaluated by the school evaluation leadership working group, and the teacher's personal debriefing and professional development performance display, expert review. After the results of the assessment are published, the school confirms the results of the assessment. The evaluation process is as follows:

a) The teacher summarizes and fills out the assessment form, and submits all supporting materials to the teaching unit for review.

b) The teaching unit shall conduct a review according to the materials submitted by the teacher. If there is any error, return it to the teacher for verification; if it is correct, submit the materials to the Academic Affairs Office, the 
Scientific Research Office, the Student Office and other functional departments for review.

c) The functional department reviews and submits it to the personnel office for review.

d) After review by the Personnel Office, submit it to the evaluation leadership working group.

e) The evaluation leadership working group organizes teachers to conduct personal presentations and performance presentations, and organizes expert reviews.

f) The results of the evaluation are publicized.

g) After the results are publicized without objection, the school confirms the results of the evaluation.

3) Use of Evaluation Results.

Learn from the "point household system" practice, and implement the "point-based salary adjustment". The points earned by the young teachers can be applied for the salary according to the points [11], and the school rewards the teachers according to the standard of 200 points per point. Of course, depending on the economic strength of the school itself, 1 point can be awarded a bonus of 300 yuan or 400 yuan, or even higher. The integration period is one academic year. During the evaluation period of one academic year, the average of the points of all young teachers is calculated. For young teachers above the average value, the school may consider raising their salary by one level. Young teachers below the average value are maintained the original salary level and participate in the next year's point evaluation.

4) Settlement of Evaluation Disputes.

If the teacher himself disagrees with the evaluation results, he may file an appeal or reconsideration application with the Personnel Office or the evaluation leading group during the publicity period of the evaluation results. The school will review the situation according to the situation and reply within 10 working days.

\section{Problems to Be Solved in the Point-Based Evaluation System}

From the perspective of the subject of evaluation, the development goals of young teachers themselves must be clear. Although external factors are important, if you want to make breakthroughs in academics, you still have to rely on the unremitting efforts of young teachers. Young teachers should have a sense of responsibility and mission for good teaching and academic successors, and must have an objective and scientific evaluation and analysis of themselves; It is necessary to continuously enhance self-confidence, establish lofty ideals and ambitions, be brave in researching and be good at researching; be humbly learn from middle-aged and old-aged teachers, and make clear their own professional and academic development directions on the basis of their predecessors, and develop according to the situation and social needs. Make timely adjustments; properly 
handle the relationship between teaching and research, the relationship between immediate work and long-term development, the relationship between individual efforts and teamwork.

It is necessary to adhere to the unity of "quantity" and "quality" and accurately grasp the relationship between "quantity" and "quality". The requirement of "quantity" must be based on "quality". If the "quality" is sacrificed, only the requirement of "quantity" is bound to be the result of the reverse of the end of the present [12].

Schools should balance the relationship between teaching and scientific research. In addition to objectively and reasonably evaluating the performance and contribution of young teachers, young teachers should be given a certain degree of freedom to fully develop their personal goals through ability assessment to achieve maximum support for this evaluation system.

It is necessary to adhere to the scientific concept of development and the concept of talents. It is necessary to encourage some outstanding young teachers to produce high-quality achievements, improve the mechanism that encourages outstanding talents to stand out, and maximize the flexibility of private colleges and universities. At the same time, it is necessary to reform the teacher's salary system as a supporting policy.

\section{Conclusions}

After objective analysis and evaluation, the young teachers' point-based evaluation system can achieve the following expected effects: 1) it can play a better guiding role. The rules and regulations have a basic authority status within an organization. Private colleges and universities have developed a management system suitable for themselves through active exploration and reform, which must have guiding significance and guiding role. 2) Determine the professional development integral factor of young teachers, give the actual meaning of the integral factor, and establish the method of points and salary conversion. 3) The idea that can truly reflect the benefits of more works and more rewards, and to a certain extent, stimulate the enthusiasm of young teachers.

In summary, in a certain period of time, young teachers' point-based evaluation system can effectively promote the construction of private colleges and universities, enabling young teachers to grow up as soon as possible and truly become the backbone of private colleges and universities.

\section{Conflicts of Interest}

The authors declare no conflicts of interest regarding the publication of this paper.

\section{References}

[1] Li, J.M. (2015) Exploration of Teaching Staff Construction in General Medicine Education under the New Situation. In: Information, Business and Management (Lecture Notes in Management Science Volume 49), Paris, 30 December 2015, 
76-80.

http://navi.cnki.net/KNavi/DPaperDetail?pcode=CIPD\&lwjcode=ZNXX201512009 \&hycode $=022052$

[2] Fang, X.T. and Wang, D.Q. (2013) External Environment Development of Teaching Staff Construction in Chinese Independent Colleges: Take Chongqing as an Example. Canadian Social Science, 3, 90-95. http://cscanada.net/index.php/css/article/view/j.css.1923669720130903.5750

[3] Gao, C.X. (2018) The Way to Improve Young Teachers' Scientific Research and Innovation Ability. Chinese University Science \& Technology, 4, 30-31.

[4] Shi, L.J., Yao, Y.J., Xia, X.Y., Xie, X.G. and Wu, L.L. (2011) Practical Teaching Staff Construction under New Situation. International Journal of Education and Management Engineering, 2, 57-61.

http://www.mecs-press.org/ijeme/ijeme-v1-n2/IJEME-V1-N2-9.pdf https://doi.org/10.5815/ijeme.2011.02.09

[5] Li, R. (2014) Application of Integral Management in Innovative Social Management. CPPCC Newspaper, 2014-03-01 (03: Special Edition).

http://dzb.rmzxb.com/index.aspx?date=2014-03-01\&verOrder=03\&banzi=2\&paper Type $=\mathrm{rmzxb}$

[6] Feng, Z.M. (2018) Integrating System Management: Exploration and Practice of Teacher Performance Evaluation Reform in Higher Vocational Colleges. Vocational and Technical Education, 2, 63-67.

[7] Gu, L.L., Feng, Z.M. and Gao, M.S. (2017) Dispatched Teachers' Organizational Justice Appeal and Incentive Mechanism Construction of Colleges and Universities: Taking the Integral Management System of S Vocational College as an Example. Journal of Huaihai Institute of Technology (Humanities \& Social Sciences Edition), 12, 92-95.

[8] Chen, X.C. (2017) Difficulties and Mechanism Innovation in the Construction of Teachers' Ranks of Entrepreneurial Education in Local Colleges and Universities. Research on Higher Engineering Education, 6, 170-173.

[9] Adedoyin, R.A., Awotidebe, T.O., Borode, A.O., Ativie, R.N., Akindele, M.A., Adeyeye, V.O. and Johnson, O.E. (2016) Comparison of Blood Pressure Patterns of Teaching and Non-Teaching Staff of a Nigerian University. International Journal of Clinical Medicine, 7, 454-460. https://doi.org/10.4236/ijcm.2016.77049

[10] Ozdil, A., Akcam, T.I. and Cagirici, U. (2016) Preferences of the Thoracic-Surgery Academic Teaching Staff on Thoracotomy Opening/Closure and Post-Thoracotomy Pain Management. Open Journal of Thoracic Surgery, 6, 1-6. https://doi.org/10.4236/ojts.2016.61001

[11] Marina, H. and Vanessa, F. (2017) CoPs: Enhancing Quality Learning and Teaching with Sessional Staff. Communities of Practice, 11, 505-523. https://link.springer.com/chapter/10.1007\%2F978-981-10-2879-3_24

[12] Aintzane, D. and David, L. (2017) Management Teams and Teaching Staff: Do They Share the Same Beliefs about Obligatory CLIL Programmes and the Use of the L1? Language and Education, 31, 93-109. https://www.tandfonline.com/doi/full/10.1080/09500782.2017.1290102 